\title{
Study on Pattern of Different Prostatic Lesions with Reference to Serum Prostate Specific Antigen (PSA) Level among Autopsy Cases
}

\author{
Subhendu Mandal ${ }^{1}$, Krishnendu Das ${ }^{2}$ \\ ${ }^{1}$ Department of Pathology, R.G. Kar Medial College and Hospital, Kolkata, West Bengal, India. \\ ${ }^{2}$ Department of Pathology, Malda Medial College, West Bengal, India.
}

\section{ABSTRACT}

\section{BACKGROUND}

Prostatic carcinoma is now recognized as one of the most important causes of morbidity and mortality in the male population. The available statistics on prostatic cancer is based on clinically diagnosed carcinomas and those latent tumours found unexpectedly at prostatectomy and autopsy. The proportion of latent carcinomas among all prostatic cancer-cases depends on the detection rate and varies from country to country, thus casting uncertainty on the comparability of prostatic cancer statistics from different geographic areas. Early diagnosis of prostate cancer is an important issue which needs a multidisciplinary approach using Digital Rectal Examination (DRE), prostate specific antigen assay and transrectal ultrasound with guided biopsy.

\section{METHODS}

During the course of medico-legal autopsies on victims dyeing of unnatural causes, 60 prostates and approx. $5 \mathrm{ml}$ of blood from each of the same 60 cases were collected with the age ranging from 40 to 85 years. This study was conducted in the Department of Pathology, Dept. of Forensic Medicine \& Toxicology, Dept. of Biochemistry, R.G. Kar Medical College \& Hospital, Kolkata, and at the attached Police Morgue for 1 year during the period of April 2013 to March 2014. No clinical histories were available since these men had not been hospitalized. Cases were selected by random sampling method from all cadavers meeting the inclusion and exclusion criteria on the particular days on which autopsies were conducted.

\section{RESULTS}

Definitive histopathological diagnosis was obtained in 46 out of 60 cases with Benign Hyperplasia Prostate (BHP) (60\%), prostatitis (8.3\%), prostatic adenocarcinoma (8.3\%), and corresponding post mortem serum PSA level in benign lesions 0.2-27.6 $\mathrm{ng} / \mathrm{mL}$ (median value $3.76 \mathrm{ng} / \mathrm{mL}$ ), in malignancies 3.73-124.1 ng/mL (median value $41.65 \mathrm{ng} / \mathrm{mL}$ ) while in all 14 normal cases PSA ranges from 0.07 to $2.98 \mathrm{ng} / \mathrm{mL}$.

\section{CONCLUSIONS}

Correlation studies of different prostatic diseases with post-mortem serum PSA level are very few. Total PSA level in serum of deceased within 24 hours of death reflects the ante-mortem serum total PSA level. The use of autopsy prostates and PSA data would avoid diagnostic bias from use of clinical material, and permit extensive analysis to be carried out, which is very difficult with live subjects. Incidence of latent adenocarcinoma of prostate as well as nodular hyperplasia of prostate is alarmingly high in men over the age of 50 years. High post-mortem serum total PSA level (cutoff value of $4 \mathrm{ng} / \mathrm{mL}$ ) is significantly associated with adenocarcinoma of prostate.

\section{KEY WORDS}

Prostate Specific Antigen, Nodular Hyperplasia, Autopsy
Corresponding Author: Dr. Krishnendu Das, Department of Pathology, Malda Medial College, Kolkata, West Bengal, India. E-mail: drdas.krishnendu@gmail.com

DOI: $10.14260 /$ jemds/2020/186

Financial or Other Competing Interests: None.

How to Cite This Article:

Mandal S, Das K. Study on pattern of different prostatic lesions with reference to serum prostate specific antigen (PSA) level among autopsy cases. J. Evolution Med. Dent. Sci. 2020;9(11):863-868, DOI: 10.14260/jemds/2020/186

Submission 10-01-2020,

Peer Review 19-02-2020,

Acceptance 26-02-2020,

Published 16-03-2020.

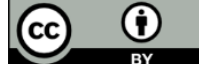




\section{BACKGROUND}

Prostatic carcinoma is now recognized as one of the most important cause of morbidity and mortality in the male population. The available statistics on prostatic cancer is based on the sum of clinically diagnosed carcinomas and those latent tumours found unexpectedly at prostatectomy and autopsy. The proportion of latent carcinomas among all prostatic cancer cases depends on the detection rate and varies from country to country, thus casting uncertainty on the comparability of prostatic cancer statistics from different areas. Early diagnosis of prostate cancer is an important issue which needs a multidisciplinary approach using Digital rectal examination (DRE), prostate specific antigen assay and transrectal ultrasound with guided biopsy. Despite these efforts, $33 \%$ of patients still present with advanced stage of the disease. ${ }^{[1]}$ Identification of premalignant lesions like prostatic intraepithelial neoplasia (PIN) and atypical adenomatous hyperplasia (AAH) assumes importance in this context and lately, they have been recognized as putative premalignant lesions of prostate.

Measurement of PSA level is an important diagnostic tool in different prostatic diseases including Prostatic Cancer. There is a direct correlation between serum PSA concentration and clinical stage. Irrespective of the treatment modality, PSA reflects accurately the tumour status of the patient and its prognostic outcome.[2] The post mortem serum PSA level (collected within 24 hours of death) reflects the ante-mortem PSA level.. ${ }^{[3]}$ Study regarding the prevalence of Prostate cancer (including the latent /occult prostatic cancer) and other prostatic pathologies in autopsy cases has not been done so much in India. The use of autopsy of prostates and postmortem PSA data can avoid diagnostic bias from use of clinical material, and permits extensive analysis, which is very difficult with live subjects.

We wanted to identify different prostatic lesions macroscopically and histopathologically among autopsy cases and evaluate the relation between them with post-mortem serum PSA level using normal prostates as internal control group.

\section{METHODS}

This study was a cross sectional study conducted in the Department of Pathology, Dept. of Forensic Medicine \& Toxicology, Dept. of Biochemistry, R.G. Kar Medical College \& Hospital, Kolkata in the period of April 2013 to March 2014. During the course of medico-legal autopsies on victims dyeing of unnatural causes, 60 prostates and approx. $5 \mathrm{ml}$ of blood from each of the same 60 cases were collected with the age ranging from 40 to 85 years. The sample was taken based on the convenience of the study. No clinical histories were available since these men had not been hospitalized. Cadavers which are unidentified, decomposed, grossly mutilated or more than $24 \mathrm{hrs}$ old are excluded from the study. Cases were selected by random sampling method, taking all cadavers meeting the inclusion and exclusion criteria on the particular days in which autopsies were conducted by the co-guide in this study, generally on every Monday. The study was approved by the Ethical Committee of the institution. The prostates were removed en block with seminal vesicles and immediately placed in $10 \%$ formalin solution for 2 days at room temperature. After proper fixation, prostates were weighed and measured in three dimensions (width $\times$ height $\times$ length) and sectioned at 4-mm intervals. Any abnormalities like increase in weight / size and gross features like nodular or cystic changes and presence of calculi were noted. The tissues were processed routinely, embedded in paraffin and conventional sections (4-6 um thick) were stained with Haematoxylin and Eosin (H\&E). Deeper sections were examined wherever necessary. It is reviewed that similar procedure was followed for sample removal and tissue processing by Alexandre R.

Zlotta et al. in 2013.[4] Histopathological examination were done and cancer diagnosed based on the criteria described in the World Health Organization (WHO) classification system, ${ }^{[5]}$ About $5 \mathrm{ml}$ of blood was collected from the heart of the deceased and serum was separated by centrifuging at 1600 2000 rpm for 10 minutes and its PSA level was measured by standard ELISA method.

\section{Statistical Analysis}

The Statistical Package for Social Science \{SPSS Version 20 will be used for Data Analysis. Mean, median, and SD are used to describe quantitative data. Qualitative data are summarized using frequency and percentage.

\section{RESULTS}

In the present study, out of 60 cases included, majority of cases 17 cases $(28.33 \%)$ was in the 50-59 years of age group followed by $60-69$ years and minimum 2 cases $(3.33 \%)$ were above the age of 80 years. The average age of the cases was $58.72 \pm 10.62$ years (mean \pm SD) with a median of 59 years and range of 40 to 85 years. In terms of religion, only 2 cases were Muslim, constituting $3.33 \%$ of total cases. Corresponding change in weight was recorded according to age. An increase in weight was observed with advancing age. Maximum weight of prostate measured was 70 grams and minimum of 13 grams. Mean weight was 35.4 gms with a standard deviation of 13.88 gms. The mean weight in 40-49 age groups was 24.15 gms with a SD of 10.16; 34.88 gms in 50-59 age group with SD of 14.68; 37.87 gms with SD of $11.02 ; 42.16$ gms with SD of $13.9 ; 52.5$ gms with SD of 6.36; in 60-69, 70-79 and 80 \&above age groups.

The mean weight of normal prostate is 16.71 gms with a standard deviation of 2.55 gms. The mean weight in different pathological prostates are between $35.33 \mathrm{gms}$ to $50.33 \mathrm{gms}$ and higher than that of normal prostate. NHP cases have a mean weight of 39.9 gms, while PIN cases have 35.33 gms and adenocarcinoma cases have a mean weight of $44 \mathrm{gms}$. Among 60 autopsy prostates, $14(23.33 \%)$ were found normal out of which 7 (58.3\%) were found in 40-49 years with no normal prostate in the $\geq 80$ years age group and $46(76.67 \%$ ) cases had variable degree of pathology.

Malignant lesion (adenocarcinoma) of prostate was found in $5(8.33 \%)$ cases mostly in $70-79$ years group and $3(5 \%)$ cases of premalignant lesion (PIN) were found. Among the 38 (63.33\%) benign prostatic lesions, most of the cases i. e. 32 $(53.33 \%)$ were NHP with distribution in 40-49, 50-59, 60-69 
and 70-79 years age groups, 6 (46.2\%), $9(52.9 \%), 9(56.3 \%)$ and $7(58.3 \%)$ cases, respectively. 2 (3.33\%) cases had prostatitis and $3(5 \%)$ had NHP with prostatitis. Only 1 $(1.66 \%)$ case of basal cell hyperplasia associated with NHP was found in 70-79 years age group.

\begin{tabular}{|ccc|}
\hline Age Groups (Years) & Number & Percentage (\%) \\
$40-49$ & 13 & 21.66 \\
$50-59$ & 17 & 28.33 \\
$60-69$ & 16 & 26.66 \\
$70-79$ & 12 & 20 \\
$\geq 80$ & 2 & 3.33 \\
Total & $\mathbf{6 0}$ & $\mathbf{1 0 0}$ \\
\hline
\end{tabular}

Table 1. Distribution of Study Population According to Age $(n=60)$

\begin{tabular}{|cccc|}
\hline Prostatic Lesions & $\begin{array}{c}\text { Mean Wt. } \\
\text { (gms.) }\end{array}$ & S.D. (gms) & Range (gms) \\
Normal $(\mathrm{n}=14)$ & 16.71 & 2.55 & $13-20$ \\
Prostatitis (n=2) & 43.5 & 16.26 & $32-55$ \\
NHP (n=32) & 39.9 & 9.9 & $25-70$ \\
NHP/Prostatitis (n=3) & 50.33 & 8.5 & $44-60$ \\
NHP/BCH (n=1) & 49 & -- & -- \\
PIN (n=3) & 35.33 & 6.8 & $30-43$ \\
Adenocarcinoma (n=5) & 44 & 16.1 & $20-60$ \\
Total (n=60) & $\mathbf{3 5 . 4}$ & $\mathbf{1 3 . 9 9}$ & $\mathbf{1 3 - 7 0}$ \\
\hline Table 2. Weight of Prostates in Different Prostatic Lesions $(\boldsymbol{n}=\mathbf{6 0})$ \\
\hline
\end{tabular}

\begin{tabular}{|ccc|}
\hline Histopathological Diagnosis & Number of Cases & Percentage (\%) \\
Normal & 14 & 23.33 \\
Prostatitis & 2 & 3.33 \\
NHP & 32 & 53.33 \\
NHP with Prostatitis & 3 & 5 \\
NHP With BCH & 1 & 1.66 \\
PIN & 3 & 5 \\
Adenocarcinoma & 5 & 8.33 \\
Total & $\mathbf{6 0}$ & $\mathbf{1 0 0}$ \\
\hline Table 3. Distribution of Cases According to \\
\multicolumn{2}{c}{ Histopathological Diagnosis (n=60) } \\
\multicolumn{2}{|}{}
\end{tabular}

\begin{tabular}{|c|c|c|c|c|c|}
\hline Cases & Mean & Median & Minimum & Maximum & \pm SD \\
\hline Normal (n=14) & 0.745 & 0.425 & 0.07 & 2.98 & 0.81 \\
\hline Prostatitis ( $\mathrm{n}=2)$ & 5.91 & 5.91 & 3.6 & 8.22 & 3.26 \\
\hline NHP $(n=32)$ & 4.65 & 3.69 & 0.2 & 27.6 & 4.97 \\
\hline NHP/Prostatitis $(n=3)$ & 7.66 & 7 & 3.92 & 12.08 & 4.12 \\
\hline NHP/BCH $(n=1)$ & 4.8 & 4.8 & 4.8 & 4.8 & -- \\
\hline PIN $(\mathrm{n}=3)$ & 6.32 & 3.8 & 2.1 & 13.06 & 5.89 \\
\hline Adenocarcinoma $(n=5)$ & 51.27 & 41.65 & 3.73 & 124.1 & 44.38 \\
\hline All Cases $(n=60)$ & 7.9 & 3.55 & 0.07 & 124.1 & 18.06 \\
\hline
\end{tabular}

Maximum number $(7,50 \%)$ of all normal prostate were found in 40-49 years age group and with increasing age number of normal prostate was decreasing having no normal prostate in the $\geq 80$ years age group. In this study the serum total PSA level for all 60 cases ranges from 0.07 to $124.1 \mathrm{ng} / \mathrm{mL}$ with a mean value of $7.9 \mathrm{ng} / \mathrm{mL}$. and median value of 3.55 $\mathrm{ng} / \mathrm{mL}$. For all 14 Normal cases PSA ranges from 0.07 to 2.98 $\mathrm{ng} / \mathrm{mL}$. and the mean PSA value for the normal cases is 0.745 $\mathrm{ng} / \mathrm{mL}$. with a median value of $0.425 \mathrm{ng} / \mathrm{mL}$. These cases are considered as internal control group in the present study.

Serum total PSA level range for all 5 malignant cases is 3.73 to $124.1 \mathrm{ng} / \mathrm{mL}$ with a very high mean of $51.27 \mathrm{ng} / \mathrm{mL}$ and median value of $41.65 \mathrm{ng} / \mathrm{mL}$. The lowest PSA value is 0.07 $\mathrm{ng} / \mathrm{mL}$. among all the 55 cases not having malignancy with a highest value of $27.6 \mathrm{ng} / \mathrm{mL}$. The mean and median value of the PSA is 3.96 and $3.0 \mathrm{ng} / \mathrm{mL}$., respectively. PSA range for all 38 benign cases is 0.2 to $27.6 \mathrm{ng} / \mathrm{mL}$ with mean value of 4.96 $\mathrm{ng} / \mathrm{mL}$. and median value of $3.76 \mathrm{ng} / \mathrm{mL}$. PSA range for all 32 cases of Nodular Hyperplasia of prostate 0.2 to $27.6 \mathrm{ng} / \mathrm{mL}$ with mean value of $4.65 \mathrm{ng} / \mathrm{mL}$. and median value of 3.69 $\mathrm{ng} / \mathrm{mL}$. Within the 3 cases on Prostatic Intraepithelial Neoplasia, the lowest PSA value is $2.1 \mathrm{ng} / \mathrm{mL}$ and the highest PSA is $13.06 \mathrm{ng} / \mathrm{mL}$. The mean value is $6.32 \mathrm{ng} / \mathrm{mL}$. and median is $3.8 \mathrm{ng} / \mathrm{mL}$. PSA for 3 cases of Nodular Hyperplasia of prostate with Prostatitis ranges from 3.92 to $12.08 \mathrm{ng} / \mathrm{mL}$ with mean value of $7.66 \mathrm{ng} / \mathrm{mL}$. and median value of 7.0 ng/mL. 2 cases of Prostatitis have PSA values of 3.6 and 8.22 $\mathrm{ng} / \mathrm{mL}$. with a mean of $5.91 \mathrm{ng} / \mathrm{mL}$. The only case of Nodular Hyperplasia of prostate with Basal Cell Hyperplasia has a PSA value of $4.8 \mathrm{ng} / \mathrm{mL}$.

\section{DISCUSSION}

Autopsy studies that have defined the incidence and morphological evolution of prostatic hyperplasia and carcinoma have been confined largely to hospital autopsy of men with more than 40 years of age. Benign hyperplasia and carcinoma of prostate are increasingly frequent with advancing age. The frequency of incidentally found carcinoma in autopsies of patients with no urological complaints varies from 6.6 to $66.7 \% .{ }^{[6]}$ It is likely that adenocarcinoma of the prostate is the most prevalent cancer in men ${ }^{[7,8]}$ although it is often discovered incidentally and may remain latent or pursue an indolent clinical course. This prompted us to investigate the spectrum of lesions in routine medicolegal autopsy specimens. Serum PSA level is a good screening test to detect early / latent prostate cancer. Men with organ confined prostatic carcinoma in early stage can be cured by radical prostatectomy and enjoy a survival rate equivalent to that of age-matched men without prostatic carcinoma.

In the present study, a total of sixty (60) autopsy specimens of prostate and their serum PSA levels were studied in the of Department of Pathology, R.G. Kar Medical College \& Hospital, during the period from April 2013 to March 2014. The age range of the cases in present study was between 40 years to 85 years with mean age being 58.71 years. Out of 60 autopsy cases 46 cases had some pathology and majority of the cases were encountered in the $6^{\text {th }}$ and $7^{\text {th }}$ decade $(58.69 \%$ of total cases) with decline in later age group The decline in the number of cases beyond the age 80 years may reflect the average life span of people in our country which rarely exceeds beyond the $6^{\text {th }}$ decade. [9]

The minimum weight seen in a study done by Pradhan and Chandra.[10] was 1.6 grams in 1-10 age group; 1.8 grams in study done by Swyer.[11] and 2.28 grams in study done by Murty and Roy.[12] for the same age group. Present study showed the minimum weight of 24.15 grams in 40-49 age groups which was higher than other studies as cases below 40 years were not present in the study. But it was similar for the same age group in the studies done by Murty and Roy.[12]

In the studies done by Murty and Roy and Tornblom et al.[13] the maximum average weight were $40.3 \mathrm{gm}$ and $34.5 \mathrm{gm}$ respectively, both seen above 71 years. The study by Ghartimagar et al.[14] showed maximum weight of 60 grams in the only 84 years old subject. The present study showed maximum weight of 52.5 grams in $80+$ years age group and it was slightly higher as only 2 cases were present above 80 years. The present study showed 42.16 grams of weight in $71-$ 80 age group correlating well with the study done by Murty and Roy.

The present study showed 5 (8.33\%) cases showing inflammation, corroborating with the study done by Men S et al.[9] in the year 2001 (10.4\%). Granulomatous prostatitis was 
not seen in this study. Mittal et al.[8] found only $1.62 \%$ of granulomatous inflammation as his number of cases were higher than the present study. Present study showed only 1 $(1.66 \%)$ case of Basal cell hyperplasia (BCH), observed at 70 years of age. The case was seen associated with NHP. Mittal et al[8] found $5.4 \%$ of BCH in his study. In the present study, NHP is the most common pathology found in prostate and is seen in a total of $36(60 \%)$ cases, including the $3(5 \%)$ cases associated with prostatitis and $1(1.66 \%)$ case associated with Basal Cell Hyperplasia: the incidence correlating with the autopsy studies done by Ghartimagar et al., Konstantinos et al[15]. and Men S. et al, the incidence being 55\%, 65.5\% and and $66.4 \%$ respectively. The highest percentage of NHP was seen in a study done by Mittal et al. (92.97\%), followed by Rekhi et al.[16] (88.5\%) and Ryusei Sasaki et al. in Japan (81\%). The percentage was high in these studies as studies were based on prostatectomy done on symptomatic patients.

Present study showed the incidence of Prostatic intraepithelial neoplasia (PIN) in 3 cases (5\%), nearer to the incidence shown by Ming Yin et al.[17] (10.6\%) and Ghartimagar et al. (16\%). Prostatic adenocarcinoma is the most common form of cancer in men and second leading cause of cancer death.[1,2]

\begin{tabular}{|c|c|c|c|c|c|}
\hline \multicolumn{6}{|c|}{ Comparison of Latent Prostate Carcinoma in Different Studies in India. } \\
\hline \multicolumn{2}{|c|}{ Study } & Year & Specimen & $\begin{array}{l}\text { No. of } \\
\text { Cases }\end{array}$ & $\%$ \\
\hline \multicolumn{2}{|c|}{ Mittal et al..$^{[8]}$} & 1989 & $\begin{array}{l}\text { Prostatectomy } \\
\text { TRUP \& biopsy }\end{array}$ & $13 / 185$ & $7.02 \%$ \\
\hline \multirow{2}{*}{\multicolumn{2}{|c|}{$\begin{array}{c}\text { Men S. et al..99] } \\
\text { Neelkamal Kapoor et al }\left[{ }^{[18]}\right.\end{array}$}} & 2001 & TRUS Biopsy & $31 / 134$ & $23.1 \%$ \\
\hline & & 2004 & RCP & $83 / 508$ & $16.4 \%$ \\
\hline \multicolumn{2}{|c|}{ Rekhi et al..$^{[16]}$} & 2004 & RCP & $23 / 200$ & $11.5 \%$ \\
\hline \multicolumn{2}{|c|}{ Desai et al.[19] } & 2004 & RCP & $3 / 44$ & 6.8 \\
\hline \multicolumn{2}{|c|}{ Present study } & $\begin{array}{l}2013- \\
2014\end{array}$ & Autopsy & $5 / 60$ & $8.33 \%$ \\
\hline \multicolumn{6}{|c|}{ Comparison of Latent Prostate Carcinoma in Different Western Countries } \\
\hline \multicolumn{2}{|c|}{ Study } & & Sample & Study & $\%$ \\
\hline $\begin{array}{l}\text { Nations/ } \\
\text { Community }\end{array}$ & Authors & Year & Type & Population & of PCA \\
\hline Vienna & A.R Rich[20] & 1935 & Autopsy & 292 & $9 \%$ \\
\hline Bristol & $\begin{array}{c}\text { G. S. } \\
\text { Andrews } \\
\text { [21] }\end{array}$ & 1949 & Autopsy & 142 & $12 \%$ \\
\hline Denmark & B. Hølund ${ }^{[22]}$ & 1980 & Autopsy & 223 & $22 \%$ \\
\hline $\begin{array}{l}\text { America } \\
\text { (black) }\end{array}$ & $\begin{array}{l}\text { Yatani R. } \\
\text { et al. }{ }^{[23]}\end{array}$ & 1982 & Autopsy & 178 & $36.9 \%$ \\
\hline $\begin{array}{l}\text { America } \\
\text { (white) }\end{array}$ & $\begin{array}{l}\text { Yatani R. } \\
\text { et al.[23] }\end{array}$ & 1982 & Autopsy & 253 & $34.6 \%$ \\
\hline Colombia & $\begin{array}{l}\text { Yatani R. } \\
\text { et al.[23] }\end{array}$ & 1982 & Autopsy & 182 & $31.5 \%$ \\
\hline Hungary & $\begin{array}{l}\text { Soos G } \\
\text { et al.[24] }\end{array}$ & 2005 & Autopsy & 139 & 38.8 \\
\hline Pennsylvania & $\begin{array}{l}\text { Ming Yin } \\
\text { et al.[17] }\end{array}$ & 2007 & Autopsy & 340 & $12 \%$ \\
\hline Greek & $\begin{array}{l}\text { Konstantinos } \\
\text { et al.[15] }\end{array}$ & 2007 & Autopsy & 212 & $18.8 \%$ \\
\hline Present study & & 2014 & Autopsy & 60 & $8.33 \%$ \\
\hline Table 5. Co & mparison of 1 & Latent & $\begin{array}{l}\text { Prostate Carc } \\
\text { Id Western Cou }\end{array}$ & $\begin{array}{l}\text { inoma in Diff } \\
\text { untries }\end{array}$ & ferent \\
\hline
\end{tabular}

Table 5. shows that the incidence of prostatic cancer in this study $(8.33 \%)$ is corroborating with most of the Indian studies but most of the Western countries showed much higher incidence of latent prostatic carcinoma. The mean age of prostatic carcinoma in the present study (72.6 years) is similar to that shown in the study done by Pan J et al. (70.3 years). All of the cases were found in older ages ( $>65$ years of age) as also shown by Ali Zare-Mirzaie et al.[25] in 2012, where the tumours were more frequent in $>65$ years of age. Present study shows that prostatic carcinoma occurs earliest at the age of 65 years. G. S. Andrews [21] in 1949 and Sakr WA et al.[26] in 1993, showed that carcinoma was not found before the age of 40 . But Shinji Fujikawa et al.[27] and Soos G et al.[24] in 2005 showed that prostatic adenocarcinoma were first detected in the 3rd decade and show a steady increase with age.

This series shows that the incidence of prostatic carcinoma has a tendency towards age- dependent increase and is higher at older age groups. Out of total 5 cases of adenocarcinoma, 1 (6.25\%) was found in 60-69 years, 3 (25\%) in 70-79 years and $1(50 \%)$ case in $\geq 80$ years age group. Same findings were also shown by Alexandre R. Zlotta[4] in 2013, Ali Zare- Mirzaie et al.[25] in 2012, Shinji Fujikawa et al.[27] in 2005 and by almost all other studies in India and other countries. Clareann $\mathrm{H}$. Bunker et al[28] (2000) showed a very high age- specific rates of screening detected prostate cancer in West African population: $1 \%$, ages $40-49$ years; $7 \%$, ages $50-59$ years; $18 \%$, ages $60-69$ years; and $28 \%$, ages $70-79$ years.

In the present study, major age specific prevalence of both BPH and LPC is observed in men of the eighth and ninth decade but BPH began to manifest in the male population earlier; as also shown by Konstantinos S et al.[15] in 2007. Mean age of PIN in present study (61.66 years) is same as in a study by Troncoso et al.[29] (63.5 years). This study finds 58 years as minimum age of PIN, but many studies showed that PIN can affect prostate at an earlier life, even at third decade as shown by Sakr WA et al.[26] Muslims may have higher prevalence of prostate cancer. But the present study couldn't able establish relationship of religion with prostatic diseases could not be evaluated in the study because of the very small number of cases in a group. In this study total PSA was measured by ELISA method in the serum prepared from blood collected from the heart of the deceased within 24 hours of death; and this reflects the ante mortem serum total PSA as documented by Richard F. Jones et al. in 2005.

For all 14 normal cases PSA ranges from 0.07 to $2.98 \mathrm{n}$ $\mathrm{g} / \mathrm{mL}$. and the median PSA value for the normal cases is 0.425 $\mathrm{ng} / \mathrm{mL}$. In this study PSA range for all 38 benign cases is 0.2 to $27.6 \mathrm{ng} / \mathrm{mL}$ with median value $3.76 \mathrm{ng} / \mathrm{mL}$. Serum total PSA level range for all 5 malignant cases is 3.73 to $124.1 \mathrm{ng} / \mathrm{mL}$ with median value $41.65 \mathrm{ng} / \mathrm{mL}$. This value is significantly ( $\mathrm{p}$ $=0.0001$ ) higher than the median PSA value of $3.69 \mathrm{ng} / \mathrm{mL}$ in NHP cases (range is 0.2 to $27.6 \mathrm{ng} / \mathrm{mL}$ ), which is similar to the observed value $(3.96 \mathrm{ng} / \mathrm{mL})$ by JM Wolff et al [30] in 1996. In spite of a statistically significant difference ( $p=0.0001)$, serum PSA values overlapped considerably in both benign and malignant groups in the present study as was found in the study done by JM Wolff et al. [30] $(p=0.0001)$. Ryusei Sasaki et al.[31] (2000) also showed that there was a significant difference in total PSA between patients with PCa and BPH (p $<0.001$ ).

The presence of isolated PIN does not show a significant elevation of serum PSA (mean PSA of PIN cases is $3.8 \mathrm{ng} / \mathrm{mL}$ ), as observed by Kim HL, Yang XJ [32] in 2002 with a mean PSA value of $1.9 \mathrm{ng} / \mathrm{mL}$ and by Alexander EE et al.[33] in 1996, but Brawer MK, Lange PH.[34] (1989) showed that PIN may be associated with elevation of the serum PSA. Clinically inapparent prostatitis leads to mild increase of PSA (median is $5.91 \mathrm{ng} / \mathrm{mL}$ ). Out of 2 cases of Prostatitis one showed high level of PSA ( $8.22 \mathrm{ng} / \mathrm{mL}$ ), but less than $10 \mathrm{ng} / \mathrm{mL}$. NPH with inflammation leads to increase in PSA-serum levels (median is $7 \mathrm{ng} / \mathrm{mL}$ ) as compared to serum values of PSA in NHP without any prostatitis (median is $3.69 \mathrm{ng} / \mathrm{mL}$ ). Out of 3 cases of Nodular Hyperplasia of Prostate with Prostatitis 2 cases (i.e. $66.66 \%$ ) showed a rise of $\mathrm{PSA}>4 \mathrm{ng} / \mathrm{mL}$ and 1 case $(33.33 \%)$ showed a PSA level $>10 \mathrm{ng} / \mathrm{mL}$. All these findings in this study 
is similar to the observations in the study by Block T et al.[35] in the year 1993 showing $19.5 \%$ patients of BPH with prostatitis having serum PSA values of $>10 \mathrm{ng} / \mathrm{mL}$.

PSA value of $4 \mathrm{ng} / \mathrm{mL}$ as a screening tool and cases are divided according to the total PSA value thus so far obtained and found that $42(70 \%)$ cases have PSA value $<4 \mathrm{ng} / \mathrm{mL}$ and $18(30 \%)$ cases have PSA $>4 \mathrm{ng} / \mathrm{mL}$. having same findings as by Shalini Agnihotri et al[36] (2014-June). They found that 70.9 per cent patients had PSA of less than $4 \mathrm{ng} / \mathrm{mL}$ and 29.1 per cent had PSA of more than $4 \mathrm{ng} / \mathrm{mL}$. Present study shows that prostate carcinoma was diagnosed in one (2.38\%) case of serum PSA level within the normal range (0-4 $\mathrm{ng} / \mathrm{mL})$ and BPH was diagnosed in $14(77.77 \%)$ patients who had serum PSA > $4.0 \mathrm{ng} / \mathrm{mL}$; same findings were shown by $\mathrm{HJ}$ Yu et al. [37] who noticed the prevalence of prostatic carcinoma to be $2.7 \%$ in cases having PSA $<4 \mathrm{ng} / \mathrm{mL}$ and prevalence of NHP to be $75 \%$ of cases who had serum PSA $>4.0 \mathrm{ng} / \mathrm{mL}$.

In the present study, the tests of validity like sensitivity, specificity and positive predictive value of serum total PSA test having a cut-off value of $4 \mathrm{ng} / \mathrm{mL}$ to differentiate prostatic carcinoma from benign lesions are $80 \%, 74.54 \%$ and $22.22 \%$. Positive predictive value is similar to that shown by $\mathrm{HJ} \mathrm{Yu}$ et

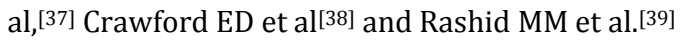

\section{CONCLUSIONS}

There are plenty of autopsy studies on prostate world-wide, many in India, but studies to correlate different prostatic diseases with post-mortem serum PSA level are very few. Total PSA level in serum of deceased within 24 hours of death reflects the ante-mortem serum total PSA level. The use of autopsy prostates and PSA data would avoid diagnostic bias from use of clinical material, and permit extensive analysis to be carried out, which is very difficult with live subjects. Incidence of latent adenocarcinoma of prostate as well as nodular hyperplasia of prostate is alarmingly high in men over the age of 50 years. Adenocarcinoma of prostate is now the leading cause of cancer death in elderly individuals. High postmortem serum total PSA level (cut-off value of $4 \mathrm{ng} / \mathrm{mL}$.) is significantly associated with adenocarcinoma of prostate. There may be controversies worldwide regarding the value of serum total PSA in the screening of the prostate diseases but the test is a good screening modality which is cost-effective and non-invasive and has high positive predictive value.

\section{REFERENCES}

[1] Mettlin C, Jones GW, Murphy GP. Trends in prostate cancer in the United States, 1974-1990: observations from the patient care evaluation studies of the American College of Surgeons Commission on Cancer. CA Cancer J Clin 1993;43(2):83-91.

[2] Epstein JI. The lower urinary tract and male genital system. In: Kumar V, Abbas AK, Fausto N, eds. Robbins and Cotrans Pathologic basis of diseases. $8^{\text {th }}$ edn. Philadelphia: Elsevier 2010: p. 993-1002.
[3] Jones RF, Sunheimer R, Friedman H, et al. Comparison of ante- and post-mortem PSA levels for epidemiological studies. Anticancer Research 2005;25(2B):1263-7.

[4] Zlotta AR, Egawa S, Pushkar D, et al. Prevalence of prostate cancer on autopsy: cross-sectional study on unscreened Caucasian and Asian men. J Nat Cancer Inst 2013;105(14):1050-8.

[5] Sesterhenn IA. Prostate and testis tumour AFIP Genitourinary pathology: WHO classification of tumours pathology and genetics of the tumours of the urinary system and male genital organs. Washington: World Health Organization, 2003.

[6] Reiter ER, De Kernion JB. Epidemiology, etiology and prevention of prostate cancer. In: Cambell's Urology. $8^{\text {th }}$ edn. Philadelphia: Saunders 2002: p. 3003-19.

[7] Scher HI. Benign and malignant diseases of the prostate. In: Kasper DL, Fauci AS, Longo DL, et al. eds. Harrison's Principles of internal medicine. 18 $8^{\text {th }}$ edn. New York: McGraw-Hill Publications 2012: p. 796-805.

[8] Mittal BV, Amin MB, Kinare SG. Spectrum of histological lesions in 185 consecutive prostatic specimens. J Postgrad Med 1989;35(3):157-61.

[9] Men S, Cakar B, Conkbayir I, et al. Detection of prostatic carcinoma: the role of TRUS, TRUS guided biopsy, digital rectal examination, PSA and PSA density. J Exp Clin Cancer Res 2001;20(4):473-80.

[10] Pradhan BK, Chandra K. Morphogenesis of nodular hyperplasia-prostate. J Urol 1975;113(2):210-3.

[11] Swyer GIM. Post-natal growth changes in human prostate. J Anat 1944;78(Pt 4):130-45.

[12] Murty OP, Roy TS. Human prostate and ageing. JFMT 1998;15(1):17-24

[13] Tornblom N. Contribution to the discussion on the etiology of prostatic hypertrophy in man. I. The weight of prostate and seminal vesicles in men of different ages. Acta Med Scand (Suppl) 1946;170:1-9.

[14] Ghartimagar D, Naik R, Gupta A, et al. Histopathology of prostatic lesions - an autopsy study of 100 cases. The Internet Journal of Forensic Science 2012;5(1):1-9.

[15] Konstantinos S, Alevizos A, Mohamed N, et al. Associations among benign prostate hypertrophy, atypical adenomatous hyperplasia and latent carcinoma of the prostate. Asian J Androl 2007;9(2):229-33.

[16] Rekhi B, Jaswal TS, Arora B. Premalignant lesions of prostate and their association with nodular hyperplasia and carcinoma prostate. Indian J Cancer 2004;41(2):60-5.

[17] Ming Y, Sheldon B, Uma C, et al. Prevalence of incidental prostate cancer in the general population: a study of healthy organ donors. The Journal of Urology 2008;179(3):892-5.

[18] Neelkamal K, Suneel S, Kamal NG, et al. Diagnosis of malignancy of prostate. Indian $\mathrm{J}$ Pathol Microbiol 2004;47(2):186-8.

[19] Desai SB, Borges AM. The prevalence of high-grade prostatic intraepithelial neoplasia in surgical resection specimens: an Indian experience. Cancer 2002;94(9):2350-2.

[20] Rich AR. On the frequency of occurrence of occult carcinoma of the prostate. Journal of Urology 1935;33(3):215-23.

[21] Andrews GS. Latent carcinoma of the prostate. J Clin Path 1949;2(3):197-208. 
[22] Hølund B. Latent prostatic cancer in a consecutive autopsy series. Scandinavian Journal of Urology and Nephrology 1980;14(1):29-35.

[23] Yatani R, Chigusa I, Akazaki K, et al. Geographic pathology of latent prostatic carcinoma. Int J Cancer 1982;29(6): 611-6.

[24] Soos G, Tsakiris I, Szanto J, et al. The prevalence of prostate carcinoma and its precursor in Hungary: an autopsy study. Eur Urol 2005;48(5):739-44.

[25] Zare-Mirzaie A, Balvayeh P, Imamhadi MA, et al. The frequency of latent prostate carcinoma in autopsies of over 50 years old males, the Iranian experience. Med J Islam Repub Iran 2012;26(2):73-7.

[26] Sakr WA, Haas GP, Cassin BF, et al. The frequency of carcinoma and intraepithelial neoplasia of the prostate in young male patients. J Urol 1993;150(2 Pt 1):379-85.

[27] Fujikawa S, Matsuura H, Kanai M, et al. Natural history of human prostate gland: morphometric and histopathological analysis of Japanese men. The Prostate 2005;65(4):355-64.

[28] Bunker CH, Patrick AL, Konety BR, et al. High prevalence of screening-detected prostate cancer among AfroCaribbeans, The Tobago Prostate Cancer Survey. Cancer Epidemiol Biomarkers Prev 2002;11(8):726-9.

[29] Troncoso P, Babaian RJ, Ro JY, et al. Prostatic intraepithelial neoplasia and invasive prostatic adenocarcinoma in Cystoprostatectomy specimens. Urology 1989;34(Suppl 6):52-6.

[30] Wolff JM, Boeckmann W, Borchers H, et al. Prostatespecific antigen: insufficient discrimination between benign prostatic hyperplasia and organ-confined prostate cancer. Urologia International 1996;57(3):170-4.

[31] Sasaki R, Habuchi T, Sato K, et al. The clinical utility of measuring total PSA, PSA density, $\gamma$-Seminoprotein and $\gamma$ Seminoprotein/total PSA in prostate cancer prediction. Jpn J Clin Oncol 2000;30(8):337-42.
[32] Kim HL, Yang XJ. Prevalence of high-grade prostatic intraepithelial neoplasia and its relationship to serum prostate specific antigen. Int Braz J Urol 2002;28(5):4137.

[33] Alexander EE, Qian J, Wollan PC, et al. Prostatic intraepithelial neoplasia does not appear to raise serum prostate-specific antigen concentration. Urology 1996;47(5):693-8.

[34] Brawer MK, Lange PH. Prostate-specific antigen and premalignant change: implications for early detection. CA Cancer J Clin 1989;39(6):361-75.

[35] Block T, Breul J, Rotter M, et al. Influence of histologically proven signs of prostatitis on serum concentration of Prostate-Specific Antigens (PSA). Aktuelle Urologie 1993;24(3):126-8.

[36] Agnihotri S, Mittal RD, Kapoor R, et al. Raising cut-off value of prostate specific antigen (PSA) for biopsy in symptomatic men in India to reduce unnecessary biopsy. Indian J Med Res 2014;139(6):851-6.

[37] Yu HJ, Chie WC, Hsieh CH, et al. Clinical efficacy of prostatespecific antigen testing in patients with prostate disease. Journal of the Formosan Medical Association 1996;95(10):782-8.

[38] Crawford ED, Leewansangtong S, Goktas S, et al. Efficiency of prostate-specific antigen and digital rectal examination in screening, using $4.0 \mathrm{ng} / \mathrm{mL}$ and agespecific reference range as a cut-off for abnormal values. Prostate 1999;38(4):296-302.

[39] Rashid MM, Alam AKMK, Habib AKMK, et al. Efficacy of lower cut off value of serum prostate specific antigen in diagnosis of prostate cancer. Bangladesh Med Res Counc Bull 2012;38(3):90-3. 